\title{
PRINSIP ETIKA GLOBAL UNTUK KOTA MODERN MULTIKULTURAL
}

\author{
Togardo Siburian \\ Dosen Sekolah Tinggi Teologi Bandung
}

\begin{abstract}
This article aims to look at the principles of the idea of global ethics at the implementation of the advanced city in the present day or modern city. The concept of global ethics logically can be considered in a certain local as the common foundations of ethical living in this universal city. Using literature method, the author tries to positively see from the idea of a global ethic associated with globalism, pluralism, secularism, postmodernism, ecumenism and humanitarianism that form the concept of global ethics, which are selectively used to add the principle of good livelihood for the civilization of the world today. The author subsequently tries to see a multidimensional pluralistic city today with a conflict on religious factors, which require a more fundamental principle of unity and universal living. Therefore global ethics is not a substitute for existing religious ethics, but additional ethics for people of different religion without discrimination. So the principle can be implemented at a local anywhere, including major cities in Indonesia.
\end{abstract}

KEYWORDS: city, modern, crisis, ethics, global, consensus, religions, for all 
ABSTRAK: Tulisan ini bertujuan untuk melihat prinsip-prinsip gagasan etika global pada implementasi kota yang maju masa kini atau kota modern. Konsep etika global secara logis dapat dipertimbangkan pada lokal tertentu sebagai dasar-dasar kehidupan etis bersama dalam kota universal ini. Dengan memakai metode kepustakaan, penulis mencoba untuk melihat hal-hal positif dari gagasan etika global yang terkait dengan globalisme, pluralisme, sekularisme pascamodernisme, ekumenisme dan humanitarianisme yang membentuk konsep etika global, di mana secara selektif dipakai untuk menambahkan prinsip perikehidupan yang baik bagi peradaban dunia sekarang. Penulis kemudian mencoba melihat sebuah kota majemuk yang multidimensi masa kini dengan salah satu konflik yang dikarenakan faktor agama, yang memerlukan suatu prinsip kebersamaan hidup lebih mendasar dan universal. Jadi etika global bukanlah etika pengganti terhadap etika agama-agama yang ada, tetapi etika tambahan bagi orang beragama yang berbeda tanpa diskriminasi. Jadi prinsipnya dapat diimplementasikan pada lokal di mana pun, termasuk kota-kota besar di Indonesia.

KATA KUNCI: kota, modern, krisis, etika, global, konsensus, agama, untuk semua

\section{PENDAHULUAN}

Kota masa kini seharusnya dapat semakin beradab karena majunya pendidikan, teknologi, profesionalisme dan pergaulan warga kota di dalam kebersamaan. Tetapi pada kenyataannya 
perbedaan dan persinggungan kecil masih banyak terjadi yang bisa mengakibatkan kerusuhan antar-lingkungan, kampung, RW/RT, apalagi persoalan-persoalan di antara orang yang berbeda keyakinan. Dinamika perkotaan yang maju dan dinamis membuat adanya keterbukaan akan perbedaan dan mengusahakan solusi yang damai.

Hal itu sebenarnya tidak lepas dari kerjasama antarwarga yang juga adalah makhluk sosial, makhluk rasional bahkan makhluk agama. Ini adalah dasar makhluk peradaban masa kini sekaligus fondasi pembangunan manusia yang seutuhnya dalam kebangsaan dan persaudaraan. Memang secara normatif, kota modern sudah mencanangkan hal-hal yang kondusif bagi kemajuan lingkungan dan masyarakatnya demi pembangunan bangsa. Dengan demikian, kota masa kini memerlukan prinsipprinsip kehidupan universal yang dapat dipakai secara bersama-sama untuk kebersamaan hidup bagi semua golongan sosial yang berbeda.

Kemunculan "etika global" patut disyukuri sebagai suatu dasar universal dalam hak-hak asasi manusia untuk mencapai masyarakat yang adil dan damai dalam dunia yang semakin kompleks dalam multi dan antardimensi. Sejak dicanangkan etika global ada banyak prinsip kebaikan umum bagi masyarakat yang berbeda agama. Gagasan etika dunia ini bermain dalam level eksternal agama dengan menggunakan pendekatan filosofi hidup mengenai kemanusiaan dalam keberagamaan di dunia multidimensi. Namun sayangnya banyak orang beragama menolaknya mentah-mentah sebagai sinkritisme, dianggap barang haram dalam beragama. Padahal 
sebagai etika, prinsipnya bermain dalam level kehidupan bersama di dalam masyarakat, bukan soal pencampuran ajaran agama yang berbeda.

Di sini masyarakat kota dapat menimbang hal-hal baik yang dapat dihubungkan dengan prinsip kedamaian orang beragama sebuah kota berdasar prinsip golden rule-nya, yang berasal dari ajaran etis minimal dari agama-agama yang berbeda dapat menjadi titik temu peradaban global.

\section{KOTA MASA KINI DAN KEBUTUHAN AKAN SUATU ETIKA GLOBAL, KOTA MODERN: KRISIS DAN TANTANGANNYA}

Kota modern yang dimaksud adalah kota besar yang setara dengan ibukota provinsi atau sedikitnya kotamadya. Kota masa kini dengan isu-isu kekinian penduduknya secara multikehidupan. Jadi kota modern di sini bukan dalam arti soal sejarah zaman modern yang sudah lalu, melainkan soal kemanusiaan masa kini sekaligus masa depannya. Di mana cita-cita sebuah kota besar sekarang harus lebih luas dan ideal daripada sekadar masalah-masalah sosial urban atau teknologi perkotaan. Konsep urban adalah dinamika kehidupan 'di dalam kota' secara psikis dan sosial dalam proses urbanisasi secara evolusional dalam kependudukan, perumahan, pendidikan, perdagangan dll.

Pergumulan kota besar masa kini harus melampaui isuisu dinamis perkotaan di atas, tetapi harus melampauinya dalam menghadapi permasalahan-permasalahan besar proses peradaban manusia yang multi-dimensi untuk menuju 
kehidupan masa depan. Kota besar (city) masa kini harus melihat manusia dalam kompleks kehidupannya di dalam proses-proses peradaban manusia, teknologi modern, pendidikan dan ilmu pengetahuan yang maju di dalam masyarakatnya. Disini diperlukan pemikiran manusia yang maju, terbuka dan inklusif serta menjauhkan diri dari barbarianisme. Kota besar ini dibedakan dari kota kecil (town) yang lebih bersifat pedesaan, tradisional dan monolitik. Ekses dari kota besar adalah secara ekonomi mungkin kemiskinan dan marginalisasi, etnosentrisisme bagi budaya dan dapat bermuara pada fundamentalisme sekaligus pluralisme dalam keagamaan dan keberagamaannya manusia. Efeknya adanya gaya hidup pamer, gemerlap, persaingan, individualisme yang dapat bermuara pada keterasingan individu. Jadi paradoks kota modern adalah alienasi, intoleransi.

Alienasi adalah segi psikologis, sedangkan intoleransi dari segi sosiologis. Yang paling berbahaya untuk peradaban kota adalah intoleransi, khususnya intoleransi agama, karena dapat menghancurkan masyarakat lebih besar. Sedangkan alienasi merusak kehidupan individu saja. Sedangkan asimilasi dianggap sangat berbahaya, khususnya dalam agama dan suku di dalam pluralisme karena dianggap pencampuran dan sinkritis. Alienasi berbahaya karena manusia tidak mau tahu satu dengan yang lainnya, tidak mengenal tetangganya. Sedangkan bahaya intoleransi karena solidaritas ekstrim segolongan orang dan menganggap yang berbeda itu sebagai musuh dan orang lain. Permusuhan agama dalam masyarakat paling berat ditanggung dunia ini, sedangkan alienasi adalah 
musuh dari diri sendiri dalam proses urbanisasi. Namun pluralisme sebagai wacana sosial dan intelektual harus dipertimbangkan warga kota pluralistik dan multidimensi ini. Studi pluralisme tidak harus langsung dituduh sebagai pendekatan agama-agama yang mencampuradukkan (asimilasi). Di sini pendekatan pluralisme agama-agama adalah negatif, sama dengan pendekatan eksklusivisme agama pun harus ditolak dalam kota modern karena tidak toleran.

Karakteristik kota modern dengan peradaban masa kini yang serba multi dalam ras, agama, bangsa, suku dan nasionalitas di dalam satu lokasi kota. Kota besar merupakan kota urban dan kota internasional dengan akses global. Ini yang dikatakan global village, di mana dihubungkan dengan karakter untuk teknologi dan ilmu pengetahuan yang terbuka dan maju, telekomunikasi dan informasi media masa dan dunia maya yang tak terbatas, kemajuan pendidikan lintas budaya dan etnik, relasi ekonomi lintas bangsa dan politik, termasuk lintas agama. Kondisi multi segala ini terkait dengan konsep "dunia dalam kota", hal-hal sedunia ada dalam satu kota. Jadi yang dilihat adalah idealisme suatu kota sebagai entitas keseluruhan kondisi, karakter, mentalitasnya, cita-cita kedamaian dan perdamaian. Di sini visi warga dan pemerintah atas kota dipertaruhkan demi cita-cita yang terkaitkan dengan warga dunia secara global.

Jadi agama di dalam sebuah kota tidak bisa dihindari. Dia berjalan dalam pemeluknya yang beraneka. Faktanya di setiap kota besar ada kuil, masjid, gereja, dan institusi agama semakin bertumbuh. Paradoks sebuah kota besar yang multi-konteks 
dan permasalahan multidimensi adalah alienasi dan intoleransi, yang pertama ada faktor psikologis dan yang kedua faktor sosial. Warga kota beragama tidak sama dengan kota agama. Kota agama bukan kota modern yang majemuk dan pluralistik. Kota beragama tidak sama dengan kota yang bernilai keagamaan pada penduduknya.

Di sini perlunya proposal baru karena problem harus ada "new type engagement" dalam "new agenda of humanity", "new action" dan "new program of education" dalam masyarakat yang global. ${ }^{1}$ Di sini awal konsep "The world in the city" seperti kota kosmopolitan, dunia dalam satu kota modern melalui media sosial dan media massa. Kota kosmopolitan terkait dengan internasionalisasi bangsa dalam kota yang multi-peradaban, multiras, dan multibangsa. Sifatnya sangat diversitas dan pluralistik dari segala arah hidup dengan segala perbedaan hidup dan perjuangan hidup bersama. Ini perlu adanya dasar-dasar hidup bersama dalam perikemanusiaan dan etika universal serta prinsip pluralisme sosial dalam penyelesaian masalah global dan regional dalam persaudaraan umat manusia. Di sinilah pentingnya etika semesta yang mengglobal dengan nilai-nilai universal diperlukan bagi masyarakat kota modern yang pluralistik agar terhindar dari ekses barbarianisme yang muncul sekarang ini. Khususnya bagi warga kota modern yang religius, maka cita-cita kota modern yang beradab dapat menimbang beberapa konsep dan prinsip

${ }^{1}$ Elenor Scott Meyers, Envisioning The New City : A Reader on Urban Minstry (Louisville: Westmister/JKP, 1992), 19, 25. 
positif di balik gagasan etika global tersebut.

Untuk mencapai 'kota yang damai' perlu adanya rekonsiliasi bagi luka-luka yang sudah ada, sehingga ada shalom di dalam kota berdasarkan keagamaan. Umat beragama perlu dan harus menjadi peace maker, ini bukan dengan kekerasaan dan paksaan. Kedamaian adalah hak dan kewajiban manusia berperadaban modern sekarang ini, karena itu pentingnya toleransi, kebebasan berbicara dan berkeyakinan. Di sini manusia modern didorong menjadi peace making kedamaian dan rekonsiliasi (pendamaian). Jadi bukan arena ekonomi saja tetapi juga arena intelektual dan artistik untuk membangun antara yang baik dan yang jahat. ${ }^{2}$ Di sini bagaimana pengelolaan kota modern dengan cara baru memasukkan visi baru ke dalam komunitas kota dan pemerintahnya. Jadi "mengusahakan kesejahteraan kota" sebagai public responsibility, di mana bukan sekadar peran politik semata, tetapi lebih dari itu "faithfull engagement with the larger issues that effect daily life... to enhance life and to change neighbourhood outcomes. To seek peace of the city means... to be active participants -not spectator- working to bring altenatives forms of urban life into being. ${ }^{3}$ Bukan hanya menjadi technopolis dengan segala alienasinya dan perasaanperasaan sendiri tertolak dan tidak berharga karena dinamika

2 David Shepard, Built as a City: God and The Urban World (London Sidney Auckland : Hodder and Stoughton, 1985), 20-21.

${ }^{3}$ Mark G Gornik, To Live in Peace: Biblical Faith and The Changing Inner City (Grand Rapids: Eerdmans Pub Co., 2002), 120. 
perkotaan yang dikatakan sebagai secular world. Secara religius, disini perlu gagasan "spiritualitas baru" yang lebih luas, terbuka, dan toleran dalam persaudaraan umat manusia, bukan hanya kekeluargaan golongan,tetapi juga membangun masyarakat dan dunia. Masyarakat beragama juga berperan penting dalam kebaikan moral dan etis dari agamanya, karena aksiomanya tidak ada agama yang jahat.

\section{KONDISI MASYARAKAT DALAM KOTA MODERN}

Berbeda dari masyarakat tradisional-pedesaan yang cenderung monolitik dan homogen, di mana agama menjalankan baik fungsinya sebagai pemersatu, melalui penguatan pada nilai-nilai adat istiadat dll. Di dalam masyarakat perkotaan yang pluralistik, agama mungkin saja menurun nilai pemersatunya dari segi tersebut, namun ini harus dicari jalan keluar, misalnya kesatuan nilai-nilai kehidupan yang lebih besar berdasarkan solidaritas dan persaudaraan umat manusia.

Dua orang sosiologis masa lalu, Tonnies dan Durkheim membantu kita memahami sosiologi perkotaan dalam dua pengertian kontras. $^{4}$ Tonnies melihatnya dengan membandingkan sosiologi pedesaan Eropa, di mana ada dua macam kehidupan sosial: 1) gemeinschaft (karakter desa tradisional) dan, 2) gessellschaft (karakter kota modern). Sebagai karakter gaya hidup kota modern dengan kualitas:

${ }^{4}$ Lihat James L. Spates dan John J. Macionis, Cities: An Abridgement of The Sociology of Cities, $2^{\text {nd }}$ ed. (Eugene: Wipft \& Stock Pub., 1996), 102-105. 
individualisme, impersonal arena relasi-relasi dan perhatian kemanusiaan yang telah memudar dibandingkan gessellschaft.

Durkheim secara analogis melengkapi dengan dua term berlawanan: pertama, "solidaritas organik" dalam perkotaan yang lebih menekankan tujuan yang sama dan kebersamaan mutualistik dari fungsi-fungsi organisme: kedua "solidaritas mekanik" yang lebih menekankan peran-peran antar-keluarga yang tetap dalam prinsip komunalisme tertentu. Namun kedua orang ini membawa kita pada satu persamaan bahwa perkotaan adalah gaya hidup masyarakat dengan kualitas plural dan individual yang oleh George Simmel telah disoroti dari sudut psikologi-sosialnya dengan sebutan 'mentalitas metropolis' dalam ciri-ciri khas seperti: proses diskriminasi, lebih intelektual, spesialis, apatis, dan akhirnya jatuh pada sistem mesin. ${ }^{5}$ Yang lain menambahkan ciri khas "impersonal" pelayanan publik yang sedikit banyak mengandung kepositifan kalau dipakai pada tempat yang sewajarnya, khususnya dalam hal impersonalisasi sosial tingkat keberagamaan anggota masyarakat. Sisi ini penting dalam rangka krisis perikemanusiaan dan kelangsungan peradaban manusia yang ditimbulkan oleh ekses negatif dari salah satu agama. (Sedangkan kenegatifannya, secara umum akan membuat manusia teraliensasi di dalam masyarakat kotanya).

Di sinilah pentingnya konsep solidaritas yang mencakup seluruh golongan manusia, seperti yang ditawarkan dalam etika global. Dalam keadaan demikian, umat beragama yang

${ }^{5}$ Ibid., 106-107. 
berlainan di dalam satu kota, apalagi ibukota dapat melangsungkan pembangunan di segala bidang dengan aman, adil, dan makmur. Masyarakat kota memang pada awalnya bersifat desa primitif, dan kemudian mengalami urbanisasi, modernisasi dan sekularisasi. Kota terbentuk dari berbagai macam aspek, dengan segala macam peradaban modern yang mendukung serta filsafat hidup yang muncul seperti: individualisme dan sekularisme bahkan globalisme. Setiap ibu kota setempat mempunyai 3 karakter niscaya pertumbuhan metropolitan: 1) perluasan demografis akibat peningkatan populasi, 2) keharusan penambahan teknologis, khususnya alat transportasi akibat banyaknya orang keluar, 3) perluasan ekonomis dalam hal pemerataan pendapatan untuk kesejahteraan warganya. ${ }^{6}$ Bahkan lebih lagi, kota-kota sangat besar (megapolitan) di dunia sedang bergerak ke arah apa yang disebut "kosmopolitan," yaitu kota "internasional" dari segala arah dunia, yang lebih bersifat konseptual daripada geografis.

Dalam hal ini, secara sosial kemasyarakatan tidak terlalu berarti untuk membicarakan agama siapa yang paling benar dengan cara bagaimanapun, karena secara wajar bukan pada tempatnya mengatakan hal-hal privat keagamaan, karena akan menimbulkan polemik lebih banyak daripada kebaikan bagi diri sendiri. Namun hal-hal kebaikan bersama dari ekspresi keagamaan yang bersifat publik harus diekspresikan untuk kemanusiaan. Jadi agama dan keagamaan warga kota modern

${ }^{6}$ Lihat Edward C. Banfield, The Unheavenly City: The Nature and Future of Our Urban Crisis (Boston: Little Brown and Co., 1970), 23 dst. 
adalah bersifat publik dan privat di dalam kota yang plural. Namun yang privat seperti kepercayaan dan ajaran harus hatihati dalam penerapanya di dalam publik yang majemuk dibedakan apalagi faktor publiknya seperti kesaksian atau dakwah agama harus hati-hati diterapkan dalam dunia yang majemuk dan plural. Di sini diperlukan etika global bersama untuk suplemen terhadap etika khusus dari ajaran agama.

Secara umum, klaim agama yang baik dan paling benar harus terbukti di dalam perjalanan hidup sehari-hari. Marilah kita bersama-sama berbuat baik sebagai bukti atas klaim bahwa agama kita yang paling benar. Tentunya saya tidak menyarankan bermuka dua atau tidak konsisten bahkan berkhianat terhadap iman, sejak diakui bahwa iman adalah masalah privasi, sedangkan sisi 'agama' adalah masalah sosialpolitik dan perlu deprivatisasi agama di dalam pergaulan masyarakat luas. Agama publik yang disarankan sejauh patokan agama sipil. Prinsip toleransi dan akomodasi menjadi penting terutama dalamkota yang berkembang secara kosmopolitan masa kini.

Sikap toleran sangat penting untuk sebuah kota modern yang bersifat kosmopolitan adalah karakter dan sikap waga negaranya yang sangat beradab di dalam kemajemukan. Didukung dengan prinsip demokrasi maka akan muncul apa yang disebut "masyarakat sipil" dan tentunya harus dibarengi dengan supermasi hukum agar tidak menjadi anarkhi dan masyarakat menjadi chaos. Ini akan menjadikan Bandung kondusif sebagai "kota berperadaban masa kini" untuk semua orang, segala bangsa dan setiap agama dll, dengan karakter 
penduduk kota dalam persaudaraan antarumat manusia, kebersamaan internasional bangsa-bangsa, persatuan sukusuku bangsa dan keterbukaan bagi kepercayaan agama-agama.

Gagasan the city for all merupakan gagasan modern yang mulia, dengan prinsip "menghargai perbedaan dan bekerja di dalam kepelbagaian" sebagai suatu proses di dalam perkembangan sosial. ${ }^{7}$ Dalam konsep "membedakan" adalah 'menjadikan beda dalam proses perkembangan atau pertumbuhan,' 'mengenai perbedaan antara' atau 'memisahkan antara'; sedangkan mempelbagaikan bermakna 'membuat jamak,' memvariasi, memodifikasi, melindungi terhadap kehilangan.' $^{8}$ Dalam prinsip tersebut warga kota tersebut menghimpun kekuatannya dalam hal bekerja sama dengan kepelbagaian dan konflik dalam konteks kebudayaan manusia. Di mana ada partisipasi dan partnership dalam proses perkembangan sosial kota, misalnya: perumahan, transportasi, sanitasi, pendidikan, lingkungan pekerjaan, kesejahteraan keamanan, serta menghadapi kejahatan, kemiskinan, bencana, dll.

Situasi kebingungan akhir-akhir ini adalah di mana kita kehilangan rasa kebangsaan, keindonesiaan, dan kemanusiaan. Manusia kehilangan ciri khas esensial sebagai manusia dan menurunkan dirinya menjadi non-manusia saja (tanaman, hewan bahkan mesin). Celakanya perilaku keberagamaan

${ }^{7}$ Lihat Joe Beall, ed., A City For All: Valuing Difference $\mathcal{E}$ Working with Diversity (London/New Jersey: Zed Book Inc., 1997).

8 Ibid., 8-9. 
manusia dijadikan alat atas nama Allah dan egoisme keberagamaan untuk menyangkali kemanusiaannya yang hakiki berdasarkan ketiga faktor kemanusiaan yang beradab tersebut. Keagamaan dan perkawanan serta rasionalitas manusia adalah tolok ukur hidup manusia sebagai suatu bangsa yang beragama dan bermasyarakat dalam satu kota yang berperadaban global. Namun tanpa meninggalkan identitas nasional dan kearifan lokal.

Masyarakat agama mungkin saja menolak sekularisme, tetapi pada masyarakat kota yang modern penting apa yang dinamakan "sekularisasi" kota, setidaknya dalam dua dimensi dunia: 1) desakralisasi politik dan, 2) dekonsekrasi nilai-nilai (masyarakat). ${ }^{9}$ Kedua hal ini harus dioperasikan dalam hal menghilangkan ekses negatif keberagamaan manusia dalam kehidupan sosialnya tanpa perlu menyangkali nilai-nilai individual keagamaan (hal iman) yang niscaya, dalam hubungannya dengan keberagaman manusia di masyarakat kota. Selanjutnya, pembentukan kota sekuler dan gaya modern tersebut didasarkan dengan dua prinsip global: anonimitas dan mobilitas di dalam proses sosial. Tanpa harus mengikuti semua (jalan) pikiran Cox, karena teridentifikasi sebagai sekularisme radikal di dalam konsep kota teknologis secara fungsional saja. Untuk mencoba memahami hal tersebut di dalam akomodasi sosial yang prinsipnya tetap mempertahankan identitas dalam toleransi masyarakat pluralistik.

${ }^{9}$ Lihat Harvey Cox, The Secular City (New York: McMillan Co., 1971), 19-32. 


\section{MELIHAT SPIRIT DI SEKITAR MANIFESTO ETIKA GLOBAL: PENILAIAN POSITIF}

Terlepas dari adanya faktor negatif filsafat hidup yang secara ideologis saling bersaing dengan filsafat hidup keagamaan yang berbeda, kebersamaan masyarakat yang beragam memerlukan cara hidup bersama dalam kehidupan masa kini. Ini untuk menghindari bentrok yang tidak perlu dalam kehidupan praktis dan dapat dinilai sebagai sarana kebersamaan manusia sekarang dari etika global. Adapun dasar-dasar prinsip universal dalam manifesto etika universal ini adalah penilaian positif dari ideologi dengan mengesampingkan lebih dahulu ekses negatif yang ada. Ada 6 spirit ideologis penting di balik etika dunia yang universal tersebut.

1) Globalisme adalah jiwa globalisasi bagi etika global sekaligus konteks pemikiran. Prinsip globalisme berasal dari proses globalisasi dalam konteks perkotaan dan sivilisasi dalam konteks modern. Masyarakat urban menggumulkan semua orang dari golongan yang sama, satu etnik dan lain etnik yang berdekatan. Kalau ditingkatkan menjadi metropolitan, maka cakupan pluralitas dalam berbagai aspek menjadi semakin besar dan berbeda hidup dalam satu tempat yang maju seperti ibu kota suatu negara atau provinsi. Daerah dan kota yang kosmopolitas adalah penduduk dunia yang meliputi semua darah di dunia ini, dan berkumpul dalam kehidupan bersamasama tanpa terlalu memandang lagi chauvinisme dan etnikisme. Semua kota besar, ibukota provinsi sedang menuju masyarakat internasional yang dinamakan kosmopolitanisme 
atau sedikitnya masyarakat nasional yang bergagasan metropolitan.

Dalam hal ini etika global mendapat tempat yang positif, di mana prinsip kekinian dari visi yang menunjukkan satu hal, bahwa "global civilization is not a future possibility; it is presentday."10 Selanjutnya dapat dikatakan sebagai "proyek" yang melibatkan nilai-nilai sama dari semua sistem etika agamaagama yang ada di dunia ini. Seharusnya etika global dapat terwujud sesegera mungkin karena diikat oleh pluralisme kultural, agama, dan intelektual yang ditenun bersama dengan peradaban global kontemporer yang bersifat dialogis. Jadi etika global tidak muncul secara bertahap dan natural seperti beberapa proses peradaban lalu. Ini adalah keunikan sekaligus keuntungannya, kalau saja orang beragama sampai pada tahap kesadaran akan keprihatinan manusia yang tinggi, maka etika global akan dapat diterapkan seketika. Prinsip peradaban manusia secara global selalu berisi pasangan, yaitu tanggung jawab global berdasarkan etika yang lebih mendasar secara universal di dalam lokal.

2) Sekularisme teologis adalah motif dan orientasi politis gerakan etika global, di mana keagamaan agama harus dilepaskan dari campur tangan negara. Politik dipisahkan dari agama agar keagamaan tradisional bermain dalam hal kebaikan

10 Ingrid H. Shafer dalam paper yang yang disampaikan dalam merayakan semangat menuju etika global. University of California at Berkeley, 20-21 Juni 1955 dengan judul "Philosophical and Foundations of A Global Ethic" [on line]. 
moral manusia dalam kemasyarakatan. Memang dalam arti sempit sekularisme diartikan sebagai ideologi anti-agama (ateisme), namun bukan berarti melawan agama secara politis (seperti komunisme). Untuk itu dalam tataran kemasyarakatan, agama harus direinterpretasikan atau diredefinisikan dalam terma-terma sosial etis warganegara. Memang benar bahwa teologi-teologi sekularistik pernah tersandung pada hal negatif, terkait dengan jargon-jargon favoritnya: religionless Christianity, Christian Atheism, worldly holiness, man for others, social gospel, sosial theology, contemporary church dll., yang makna inti Kristennya dikesampingkan dulu (mungkin untuk sementara).

Ini bukan berarti meninggalkan nilai-nilai inti kepercayaan spesifik dari agama-agama yang berbeda, tetapi hanya mensipilkan keberadaan orang-orangnya agar tidak mengekstrim dan bentrok di dalam masyarakat pluralistik ini. Di sini sekularisme teologis dapat diterima secara terbatas pada pembedaan (bukan pemisahan) antara kehidupan beragama (secara pribadi) dan kehidupan bersama (secara sosial-politik). Inilah yang oleh Ingrid Shaeffer disebut "spiritualitas religius sosial", yaitu suatu spiritualitas yang bersifat umum dan apriori berdasarkan 'rasa keagamaan' manusia terhadap 'Sang Transenden' tersebut. ${ }^{11}$ Tentu hal ini sejalan dengan 'spiritualitas baru' yang selama ini didengungkan oleh kaum

${ }^{11}$ Inggrid H. Shafer, “Dialogue, Spirituality, Love” electronic version copyright, Center for Global Ethic [online]. Didalamnya terkait dengan tulisannya dalam Journal of Ecumenical Studies: Global Ethic, volume 42 no 3 (Summer 2007). 
pluralis agama-agama. Tugas umumnya adalah kerja bersama untuk mencari solusi atas isu-isu bersama yang dihadapi umat manusia, seperti: ancaman perang, terorisme internasional, pembunuhan ras, pelanggaran HAM, krisis ekologis, kejahatan perang, kemiskinan dll. Tentu orang-orang humanis sekuler ini lebih leluasa untuk mengatasi problem-problem kemanusiaan dalam masyarakat dibandingkan dengan orang religius. Namun bukan tidak mungkin kaum beragama dapat mendorong lebih baik, khususnya dalam prinsip etika global ini. Untuk sebuah kota modern yang pluralisik ini lebih dikenal dengan internasionalisme dalam kebangsaan dan kemanusiaan.

3) Pascamodernisme adalah suatu era sekarang - tempat dan ruang - yang memuluskan jalannya argumen etika global dalam hal: dekonstruksionisme, spiritualisme, holisme kehidupan antar-semua golongan di planet ini, tanpa batasbatas yang kaku (atau jelas). Secara relatif (maksudnya dinamis) tidak boleh lagi ada klaim-klaim sosial agama pribadi yang paling benar keluar secara eksesif, karena semua sama hak benarnya dalam masyarakat dan secara politis. Karena spirit relatif kebenaran sehingga landasan epistemologis dari kebenaran adalah subyektif dan imaginatif. Dikatakan bahwa, "etika-etika posmodern harus menolak hal-hal seperti aturan normatif yang memaksa dan mencari suatu hal-hal dasar, halhal universal, dan hal-hal mutlak" serta diperhadapkan dari perspektif baru pada "isu-isu seperti hak-hak asasi manusia, keadilan sosial, konflik antar-persatuan yang penuh dengan kedamaian dan penonjolan diri (individual, dan pertentangan antara tingkah laku individu) dengan kesejahteraan bersama." 
${ }^{12}$ Di era inilah etika global telah mendapat pembuahan yang subur.

Etika global dikatakan sebagai anak zaman dari era pascamodern, di mana wacana pluralisme agama dipromosikan secara gencar dalam wacana antaragama dan studi-studi sosial. Memang ada yang kebablasan sampai pada tingkat pendekatan kredal (pengakuan iman). Secara konkrit, Swidler dalam "Toward UDGE" menyebutnya sebagai age of dialogue dan age of global dialogue sebagai kategori baru yang radikal. Berdasarkan prinsip umum yang berhubungan dalam memaknai kehidupan, maka dapat dideklarasikan secara layak dan dihasilkan konsensus bersama agar dapat dimengerti secara umum, yaitu berdasarkan prinsip golden rule dari etika yang adalah prinsip hidup yang didasarkan frase, "lakukan segala sesuatu yang orang lain lakukan kepada dirimu" (Matius 7). Ternyata semua agama dan filsafat etis yang berbeda mempunyai pendapat etis yang sama, seperti: Judaisme, Kekristenan, Budhisme, Islam, Hinduisme, Konfusianisme. Jadi secara khusus boleh dikatakan, bahwa etika global dimengerti sebagai fenomena masyarakat Barat era ini yang sedang diperluas pengaruhnya ke seluruh dunia agama-agama. Pascamodern sebagai pandangan dunia sekarang yang melihat tema-tema kehidupan tentang Tuhan, manusia, kekekalan, keselamatan dll., secara baru berdasarkan spirit toleransi dalam segala hal. ${ }^{13}$ Zaman ini

${ }^{12}$ George Ritzer, Teori-Teori Postmodern, terj. (Yogyakarta: Kreasi Wacana, 2006), 279.

${ }^{13}$ Pascamodernisme sebagai pandangan hidup sekarang dapat 
adalah suatu tempat berkumpul yang subur bagi keberadaan manusia secara holistik dan majemuk serta bersama-sama, walau berbeda-beda tanpa diskriminasi.

4) Moralisme [Etika]. Moralisme tidak sama dengan moralitas, yang pertama abstrak dan tanpa agama, sedangkan yang kedua konkrit dan faktual berdasarkan etika pragmatis dari agama. Tingginya pengharapan moral pada manusia membuat studi etika paling diminati dan berkembang pesat akhir-akhir ini. Penilaian positif pada bagian ini adalah atas fakta moralitas. Hal ini cocok dengan proyek golden rule dari Etika Global yang mengkaji dasar bersama dari agama-agama dan filsafat-filsafat etis di tengah perbedaan fundamental mereka demi kehidupan bermasyarakat. Hal-hal tersebut tidak memadai lagi di dalam peradaban manusia modern yang majemuk, khususnya dalam kemunculan banyak krisis tidak berperikemanusiaan dan konflik internasional. Kesadaran hakiki adalah, bahwa moralitas berarti melakukan yang sepatutnya pada umat manusia, karena menjadi manusia adalah bermoral, dan menjadi bermoral adalah menjadi manusia. ${ }^{14}$ Namun dalam hal ini semua sepakat bahwa "klaim etika global tidak dalam posisi untuk mengganti setiap sistem

melihat secara populer dan gamblang buku serial "Mari Berpikir" oleh Robert Don Hughers, et al., Pandangan Dunia: Bagaimana Orang-Orang Memandang Tuhan, terj. (Yogyakarta: Yayasan Gloria, Katalis, 2011).

${ }^{14}$ Michael Traber, "Conclusion: An Ethics of Communiction Worthy of Human Being" dalam Communication Ethics and Universal Values, ed Clifford Christians, Michael Traber (Thousand Oaks, London: Sage Publications Inc., 1997), 327 dst. 
dan ajaran etika agama-agama, tetapi sebagai suplemen bukan suatu alternatif, ${ }^{15}$ di mana setiap sistem etika tersebut tetap harus terpelihara, bukan relativisme etis. Selanjutnya dapat dikatakan bahwa moralitas dalam etika global hanyalah teori etis, bukan etika normatif. Bukan untuk etika pribadi orang beragama tetapi etika sosial di masyarakat.

5) Pluralisme (agama): ideologi ini dapat dianggap sebagai "ibu" yang langsung menelurkan etika global, khususnya wacana pluralisme agama secara studi-studi sosial. Sehingga kecurigaan dogmatis yang berlebihan terhadap usaha ini sebagai ekses negatif pluralisme agama harus dapat diantisipasi secara berkeadaban. Beberapa orang berkeberatan pluralisme agama ini muncul, karena dianggap kompromistik, khususnya dalam usaha reinterpretasi keunikan agama-agama yang ada. John Hick melihat pluralisme "as an extension of western cultural hegemony, to many Christian in Africa, India China, Asia, and the East generally." Ia mengakui bahwa konsepnya dibangun oleh Gereja Barat ketika menghadapi krisis di akhir abad ke-20 yang lalu. ${ }^{16}$ Ini termasuk pengaruh panjang era pascamodern terhadap era modern yang juga digagas di Barat. Tidak ada salahnya orang Timur berhati-hati dengan sifat hegemoninya mengingat sejarah kolonialisme masa lampau atas dunia Timur.

${ }^{15}$ Sallie King, "A Global Ethic in the Light of Comparative Religious Ethics" dalam Exploration in Global Ethics, 124.

${ }^{16}$ John Hick, A Christian Theology of Religions: The Rainbows of Faiths (Louisville: Westminster John Knox Press, 1995), ix. 
Memang pluralisme sekarang mengandung pengertian yang luas menyangkut: 1) kenyataan yang pluralistik dalam masyarakat (fakta keberagaman), 2) wacana studi sosial atau studi antaragama (holistik dan komprehensif), dan 3) pendekatan khusus dalam teologi religionum (komparatif), di mana hakikat agama-agama dipersatukan secara relatif di dalam kesamaan. Pengertian yang terakhir itulah yang menjadi akar-akar gagasan etika global, ketika Hans Kung sebagai seorang pluralis dalam pendekatannya, terbedakan dengan dua pendekatan lain: inklusivis dan eksklusivis. Pluralisme teologis memang menyatakan bahwa ada banyak agama yang secara hakiki benar kepada Allah, karena berasal dari satu Allah yang sama. Berdasarkan ide dasar pluralisme, pengakuan yang demikianlah membawa dan mendirikan masyarakat langsung dalam lapangan hidup etis di masyarakat plural, bukan lagi soal kesetaraan politis dan yuridis. Namun prinsip etikosentrisme dari tradisi pluralisme, akhirnya agama-agama menghasilkan deklarasi etika agama-agama yang bersifat universal.

Selanjutnya di tengah-tengah banyak kecurigaan etika global tersebut, masih dapat pelajaran dari perspektif seorang Muslim yang masih percaya ada banyak alasan untuk mendorong etika universal ini, karena sejalan dengan fakta Islam itu sendiri pada maksud awalnya. Hal itu diungkapkan, bahwa "The Prophet Muhammad did not wish to found a new religion. He was driven by the desire to bring people back to the original faith of Abraham... called Islam. ... and bear in mind that the word islam ... signifies submission to the will of God, 
and peace. In that sense islam is the same as salam, which is the same as the Hebrew shalom, meaning peace, with the special connotation of soundness, wholesomeness... Consequently, he took as his task the reestablishment of that prototype of Abrahamic religion, monotheism." ${ }^{17}$ Prinsip agama Ibrahim ini adalah dasar kesatuan untuk sedikitnya tiga agama Ibrahimi yang dianggap paling besar ketegangannya. Jadi pluralisme sosial dan struktural dari etika dapat diadopsi dalam kehidupan bersama, bukan pluralisme konfesi ajaran agamaagama yang berbeda. Semua agama ada keunikannya, di sinilah secara intelektual pluralisme dipakai untuk mempelajari wacana pluralitas secara komprehensif dan proporsional untuk kehidupan bersama.

6) Ekumenisme adalah tempat pertumbuhan yang paling segar dan aman bagi etika global di kalangan kristiani. Oikumenisme suatu gerakan kesatuan komunitas protestan secara interdenominasional di seluruh dunia, yang dalam perkembangannya meliputi juga agama non Kristen dalam dialog antar umat beragama. Secara tidak langsung, gerakan ekumenisme adalah sebagai 'ladang' yang menumbuhkan etika global ini sangat diterima baik di kalangan Kristen, khususnya dalam tatanan teologi radikalnya yang bersifat sosial-politik. Bahkan dalam pendapat yang terbatas dapat dikatakan sebagai 'corong' yang dominan bagi proyek etika global. Hal ini dapat

${ }^{17}$ Khalid Duran, “Leonard Swidler's Of A Global Ethics: A Muslim Perspective" paper yang dibacakan dalam Universal Declaration of Global Ethics. (online version). 
dilihat dari jurnal studi oikumenis yang memunculkan isu ini secara khusus. ${ }^{18}$ Karena selama ini kaum oikumenis memang telah lebih dahulu mengajukan inklusivisme agama yang kristosentris bahkan mengajukan pluralisme agama yang teosentris dalam pendekatan teologis dengan agama-agama berbeda.

Secara sempit dapat dinilai etika global sebagai "anak kandung" dari konsep pluralisme agama, ketika pendekatan pluralisme dalam teologi religionum tidak berhasil mewujudkan perdamaian agama di dunia. Sehingga diupayakan suatu terobosan baru dalam level etika kebersamaan yang universal. Sayangnya, seringkali kaum oikumenis ini bukan hanya membahasnya dalam level studistudi sosial dan filosofis, seperti: sosiologi agama, antropologi agama, dan fenomenologi agama, tetapi juga dipakai untuk merumuskan teologi agama pada level studi doktrinal. Akhirnya terjatuh pada rumusan teologis yang universalistik (pluralisme), sedang yang lain usaha sinkritis (inklusivisme). Kedua pendekatan tersebut bukan saja menolak ekslusivitas agama-agama, tetapi juga membuang keunikan dari agamaagama. Hal ini karena kurangnya pemahaman relasional antara unsur publik dan privat pada orang beragama sekaligus dengan ruang publik dan ruang privat. Hal ruang publik tidak memaksa unsur privat seorang beragama, dan unsur publik agama seseorang tidak menyerang masuk ke ruang privat,

${ }^{18}$ Lihat Journal of Ecumenical Studies: Global Ethic. Volume 42. No. 3 (Summer 2007). 
demikian sebaliknya. Mungkin ini yang dimaksudkan seseorang "tidak perlu menjadi religius", dalam arti sikap "tak perlu defensif" bagi Tuhan, "jangan beradu pendapat" "jangan merasa seolah paling tahu." 19 Singkatnya dalam ruang publik, sikap etis lebih didahulukan daripada sikap apologetis.

7) Humanitarianisme, ini dipakai sebagai prinsip dasar etika global yang dapat dipakai untuk tanggung jawab Kristen. Karena kaum evangelikal biasanya menolak pluralisme teologis, namun memandang fakta humanitas suatu kenyataan hidup dan bahwa manusia itu berharga dan perlu dihargai martabatnya. Di sinilah evangelikalisme sebagai gerakan ekumenikal alternatif dapat mempertahankan keunikan Kristen tanpa harus melakukan eksklusivisasi diri terhadap orang lain dalam eksklusivisme agama. Karena Kristus adalah inti kekristenan yang bersifat all inclusive bagi semua golongan manusia tanpa harus melalui proses inklusifisasi ke dalam diri sendiri dalam pendekatan inklusivisme agama. Di sinilah kaum injili secara intrinsik dan signifikan dapat menghargai penderitaan dan kekacauan yang menyangkut seluruh manusia di dunia ini dalam prinsip humanitarianistik. Dengan spirit ini, kota modern dapat dipakai sebagai public square dunia, tempat berkumpul berbagai macam manusia dari berbagai bangsa, ras, latar sosial-budaya, agama, ekonomi yang berbeda. Sikap humanitarianistik adalah suatu yang berdasarkan konsep menyayangi sesama manusia dan menjunjung tinggi harkat

${ }^{19}$ Carls Medearis, Dua Umat dan Yesus: Meraih Pemahaman dan Hubungan-Hubungan, terj. (Jakarta: Satu, 2011), 167, 169. 
kemanusiaan. Masalah-masalah inilah yang dikenal juga dengan teodisi, masalah keadilan Allah. Humanitarianisme tidaklah sama dengan humanisme, yang bertendensi antiketuhanan dan melawan ide keagamaan dari etika global itu sendiri. Sejak dulu sudah ada yang dikategorikan humanisagama dan bangkitnya orang-orang masa kini yang disebut "humanis religius yang baru" yang berusaha mengatasi dua tegangan yang muncul secara kreatif dan non-desktruktif dengan asumsi humanis, bahwa "kemanusiaan (humanity) tidak dapat dimengerti tanpa kaitan dengan Allah, dan Allah juga tidak dapat dimengerti kecuali melalui lensa pemikiran pengalaman manusia." ${ }^{20}$ Jadi harus belajar positif melampaui konten kemanusiaan sekularnya dalam kritik yang tidak berlebihan, karena asumsi ideologinya yang sekular dan antiagama. Sebenarnya dengan jiwa Kitab Suci kaum agama melampaui keprihatinan kemanusiaan ini menjadi, misalnya 'humanitarianisme Kristen'. Konon para sarjana non-injili pun mengakui jalannya tidak mudah, karena kebanyakan organisasi antaragama menghadapi kecemasan dan ketakutan kompromi pada sisi internal (jemaat dan komunitas) dan sisi eksternal (pemimpin masyarakat umum), takut akan menyebabkan kontroversi dan perpecahan, ketika mencoba membangun spirit kerja sama dan kesatuan tersebut. ${ }^{21} \mathrm{Di}$ sini memang perlu

${ }_{20}$ Untuk ini bisa membandingkan dengan Gregory Wolf, The New Religious Humanist: A Reader (New York: Free Press, 1997), xv.

${ }^{21}$ Bruce Grelle, "Scholarship and Citizenship: Comparative Religious Ethicists as a Public" dalam Explorations in Global Ethics: Comparative Religious Ethics E Interreligious Dialogue, Sumner Twiss and Bruce Grelle, eds, 
menjaga identitas diri yang kuat tanpa harus melebur, apalagi menyerang. Ini semata- mata demi kemanusiaan di dunia ini, tidak melibatkan interes pribadi antara golongan agama yang berbeda dalam maksud agamaisasi. Manusia menolong manusia bukan karena agamanya atau karena maksud keagamaan, tetapi karena kebaikan agama seorang kepada seorang manusia yang membutuhkan.

\section{PERAN MASYARAKAT ETIS-GLOBAL PADA PEMBANGUNAN LOKAL}

Prinsip "Demi Kemanusiaan" Universal dalam Cita-cita Kota

Dalam catatannya, Hans Kung sebagai penggagas utama Global Ethics menyatakan, bahwa yang pertama harus dimulai dari deklarasi agama-agama, lalu diikuti oleh deklarasi umum "In a 'Declaration for a World Ethic' the focus cannot be on the JUDICAL level of laws, codified rights and appealable paragraphs (e.g., Human Rights), or on the POLITICAL level of concrete suggested solutions (e.g., in reference to the debt crisis of the Third World), but rather only the ETHICAL level: the level of BINDING VALUES, IRREVOCABLE STANDARDS and INTERIOR FUNDAMENTAL ATTITUDES. Of course these three levels are related to each other."22 Ini hanya

\section{(Oxford: Westview Press, 2000), 51.}

${ }^{22}$ Hans Kung, "Explanatory Remarks Concerning a Declaration of the Religions for Global Ethics" trans Leonard Swidler. The Council for a Parliament of the World's Religions in Chicago commissioned me to develop a draft of a "Declaration of the Religions for a Global Ethic." (online version). 
kandungan etis kemanusiaan universal dari agama-agama yang berbeda untuk hidup bersama.

Konsensus universal ini mencakup seluruh elemen masyarakat dunia, karena "etik global" harus berkerja pada semua level: sarjana, pemimpin, dan akar rumput; jika tidak maka akan gagal total. Dalam level etis itulah konsensus ini dicetuskan dalam perjanjian universal, untuk diberlakukan secara normatif dalam segala lapangan kehidupan, seperti:

1. Kami saling bergantung. Masing-masing dari kami bergantung kepada 'kebaikan' semuanya, karenanya kami menghormati komunitas makhluk hidup, umat manusia, binatang, tumbuhan, dan bagi pemeliharaan bumi, udara, air dan tanah (dipersingkat).

2. Kami harus 'memperlakukan orang lain' sebagaimana kami ingin orang lain memperlakukan kami. Kami membuat komitmen untuk menghormati kehidupan dan martabat, individualitas dan keragaman, sehingga setiap orang diperlakukan secara manusiawi, tanpa kecuali (dipersingkat).

3. Kami menganggap 'semua manusia sebagai keluarga.' Kami harus berusaha berbuat baik dan murah hati....Tak seorangpun dapat dianggap dan diperlakukan sebagai warga negara kelas dua, atau dieksploitasi dengan cara apapun (dipersingkat).

4. Kami mengikatkan diri kepada 'budaya tanpa kekerasan,' penghormatan, keadilan dan perdamaian. Kami tidak akan menindas, melukai, menganiaya, atau membunuh orang lain, meninggalkan kekerasan sebagai cara untuk mengatasi perbedaan. 
5. Kami berjuang untuk sebuah 'tatanan sosial dan ekonomi yang adil,' di mana setiap orang mempunyai kesempatan yang sama untuk meraih 'potensi yang penuh sebagai manusia.' Oleh karena itu, kami mengikatkan diri kepada etik global (dipersingkat).

6. Kami mengajak semua orang, beragama atau tidak, untuk melakukan hal yang sama.

Secara keseluruhan deklarasi etika global adalah bagi umat manusia agar diperlakukan secara manusiawi. Prinsip "demi kemanusiaan" ini menghadirkan batas-batas etik yang minimal dan dimiliki bersama oleh semua agama dunia untuk menjadikan etika sebagai milik bersama. Jadi etika global adalah cara beragama anggota masyarakat global dalam level etis yang berdasarkan tradisi agama masing-masing yang berbeda dalam menangani krisis kemanusiaan. Namun prinsip global ini mengakar dalam lokal, di mana muncul lagi peristiwa memilukan umat manusia, khususnya apa yang disebut peristiwa WTC 11 September 2011, Bom Bali 1 dan 2, serta peristiwa bom di Hotel J.W. Marriot dan Kedubes Australia di Jakarta. Semua peristiwa itu menjadi catatan tragis umat manusia dalam dunia masa kini. Hal ini menyiratkan betapa susahnya kesadaran hati manusia dipulihkan, apalagi kalau sudah ada dendam membara akibat perbedaan agama dan permusuhan ideologis. Beberapa orang mungkin menyatakan bahwa pelaku bom itu bukanlah orang beragama.

Penduduk kota apapun di dunia tidak dapat membuang fakta dan menutup mata bahwa pelakunya mengatasnamakan agama dan kebanggaan jargon politik tertentu. Memang mitos 
ini terus dipelihara oleh masyarakat modern dan beradab. Tidak salah kalau harus mengakuinya sehingga dapat mencari jalan rasional untuk tidak mengulanginya. Apakah harus malu mengakui bahwa agama juga dapat berekses negatif kalau tidak dipahami secara komprehensif dalam kaitannya dengan masyarakat luas? Sudah waktunya masyarakat agama berpikir jernih dalam konteks pluralitas dan bahkan lebih dalam lagi pada wacana pluralisme agama yang lebih kritis dan intelek agar ekstrimisme atas nama agama dapat dihindari dan sikap serta tindakan barbarisme dapat ditolak oleh orang kota yang maju. Kota modern yang pluralistik harus meninggalkan prinsip lama ius regio cuius religio, agama penguasa adalah agama suatu daerah. Prinsip ini ketinggalan zaman dan melanggar HAM karena bersifat pemaksaan.

Gagasan global tanpa implementasi lokal hanya akan menjadi pajangan yang mati dan tidak berbuah, karena hanya indah di menara gading pemikiran. Wacana global mengimplikasikan adanya permasalahan lokal, dan permasalahan lokal pasti ada solusi globalnya dalam tatanan konseptual. Konsep baik itu harus teraplikasi dalam menanggulangi pergesekan sosial dalam kota yang majemuk. Di sini pendidikan budi pekerti mengenai kemanusiaan yang global harus mulai ditanamkan sejak kecil, agar terhindar dari kesempitan berpikir, sehingga dapat hidup bersama. Konsepkonsep demi kemanusiaan universal harus dilihat sebagai solusi alternatif pada masyarakat lokal dari suatu bangsa dan dunia. Jika tidak, akan menjadi ide yang kosong saja, sementara konflik manusia semakin menggila karena hal-hal kecil yang 
tidak rasional. Kaum beragama harus menyadari pentingnya hidup damai demi kemanusiaan secara umum, yang telah disediakan oleh prinsip etika global. Inilah saatnya pemerintah dan masyarakat kota modern mentransmisikan etika global dari tingkat konseptual pada aplikasi lokal, sebagai suatu usaha yang lebih penting.

Lokalitas suatu bangsa dan etnik serta daerah lokalitas suatu bangsa atau secara khusus pada situasi urbanisasi dan internasionalisasi terus bergerak ke arah kosmopolitanisme. Globalisme adalah satu lokalitas yang tanpa batas definitif lagi. Semuanya bersatu bahkan bercampur dalam masyarakat kosmopolitan, di mana semua orang adalah warga negara dunia. Globalisasi selalu disuntik dengan slogan "think globally act locally" namun bukan hanya slogan, tetapi memang harus diaplikasikan dalam konteks wilayah setempat, sebab kalau tidak akan menjadi sebuah utopia. Selain itu act globally boleh saja, tetapi jika terlalu muluk, maka akan kembali pada konsepkonsep atau gagasan-gagasan saja. Namun secara praktis, lokalitas dari komunitas dan wilayah harus berkarakteristik universal mengingat urbanisasi dari segala penjuru dan aspek kehidupan masuk ke dalam daerah tertentu dan berkembang dalam konteks sipilitas. Bahkan beberapa kota besar yang dikatakan metropolitan berkembang menjadi kosmopolitan, karena pengaruh globalisasi, tidak terkecuali seperti kota-kota modern di Indonesia, yang membuatnya tidak dapat berdiri sendiri, tetapi harus dapat diakses semua golongan manusia. Sangat tidak mustahil spirit kosmopolitanisme membuat kotakota modern di Indonesia menjadi kota dunia juga, yaitu suatu 
kota internasional karena pengaruh globalisme.

Pentingnya Implementasi Prinsip Global pada Resolusi Lokal

Problematika kemanusiaan sedang membayangi kehancuran peradaban manusia, akibat segelintir orang radikal yang ingin menang sendiri, dan akhirnya melenyapkan orang lain. Memang kemajuan zaman dapat membuat sekelompok manusia menjadi menyempit dan radikal ala fundamentalis. Kaum pluralis telah mencoba menyelesaikan dengan inklusivisme dan pluralisme setelah sebelumnya menolak eksklusivisme. Namun itu semua tidak berhasil meredam kekacauan yang ada dari orang beragama. Apakah etikonsentrisme adalah jalan terakhir bagi manusia?

Berdasarkan prinsip global etnikonsentrisme, kekacauan yang muncul diselesaikan pada level etis kebersamaan dalam etika universal. Inilah sebabnya sering disebut juga "etika dunia" yang bermaksud untuk menyelamatkan peradaban manusia dalam kehidupan di muka bumi ini. Proyek etika global menjadikan manusia sebagai manusia, dengan persaudaraan, kasih, perdamaian, toleransi dll. Dalam dunia selama ini, ternyata kegagalan usaha perdamaian ada dalam level hukum (kodifikasi hak-hak) dan perjuangan level politis. Di sini diperlukan level etis yang didasari pada golden rule yang adalah prinsip hidup bersama antar-orang yang berbeda, khususnya berbeda latar kepercayaan dan agama.

Prinsip praktis golden rule adalah, "jangan menjahati orang jikalau tidak mau dijahati", atau "kalau tidak mau dicubit jangan mencubit orang lain". Jadi golden rule ternyata 
berdasarkan nilai-nilai umum etika yang ada dalam setiap agama dan keyakinan. Pada dasarnya agama-agama mempunyai prinsip hidup bersama secara universal. Jadi golden rule tidak boleh dimaksudkan untuk sinkritisme, dan bukan juga suatu pilihan untuk menolak etika khusus dari agama-agama yang ada. Prinsip hidup bersama itu ditambahkan pada etika khusus agama masing-masing. Konsep etika global tidak bermaksud meniadakan etika agama yang privat, tetapi justru ditarik dari dasar hidup universal pada etika agama-agama yang sudah ada. Jadi tidak tabu bagi semua orang beragama untuk hidup bersama, dengan etika supleman di dalam masyarakat majemuk.

Karena pada masa kini, globalisasi tidak ada lagi batasbatas lokal secara nyata, yang ada hanyalah 'global village'. Konsekuensinya pada situasi global sekarang ini sejalan dengan situasi lokal. Slogannya adalah think globalby acts locally dan think locally acts global, tidak salah juga. Yang terpenting adalah implementasi konsep universal pada situasional. Kalau mengabaikan kenyataan globalisasi, maka menyebabkan dunia semakin mengecil dalam internasionalisasi kota yang kecil dan majemuk. Globalisasi adalah fakta dunia ini. Prinsip globalisme tanpa aplikasi lokal tidak berguna; demikian juga prinsip lokal tanpa implikasi global adalah tidak mungkin lagi.

\section{Peran Masyarakat Beragama dalam Pembangunan Kota}

Sebagai kota modern, tugas visioner kota adalah: 1) Mengembangkan sumber daya manusia yang handal, religius, mencakup pendidikan, kesehatan dan moral keagamaan. 2) 
Mengembangkan perekonomian kota yang adil, mencakup peningkatan perekonomian kota yang tangguh, sehat dan berkeadilan dalam rangka meningkatkan pendapatan masyarakat, menciptakan lapangan kerja dan kesempatan berusaha. 3) Mengembangkan kota sosial budaya yang ramah dan berkesadaran tinggi, serta berhati nurani, yang mencakup peningkatan partisipasi masyarakat dalam rangka meningkatkan ketenagakerjaan, kesejahteraan keluarga, pendidikan pemuda dan olahraga serta kesetaraan gender. Mungkin yang terlupakan adalah kesetaraan dalam berkeyakinan dan beribadah.

Pemikiran lanjutannya adalah, bagaimana warga kota harus bersama-sama membangun kotanya menuju cita-cita. Di dalamnya sekaligus ada kerawanan tersendiri mengingat ketaatan agama sering kali menjadi fanatisme dan tanpa toleransi (ada yang berbeda). Tanpa semangat pluralisme, persahabatan tidak mungkin dapat terwujud dalam sebuah kota modern yang besar yang multikultur, multiagama, multietnik dan multiperadaban. Jadi tinggal persahabatan yang menjamin ketenangan dan kedamaian; yang terpenting adalah kesederajatan umat manusia dalam peri kemanusiaan. Di sinilah prisip golden rule dapat diimplementasikan pada praktek kegiatan manusia yang berbeda beda dalam masyarakat kota:

- Prinsip kasih-mengasihi adalah kebutuhan alamiah manusia yang berkelanjutan dalam komunitas, bangsa dunia dan bumi untuk peradabannya. 
- Prinsip gotong-royong sosial; jangan kita menolak menolong masyarakat ketika dalam kesulitan serius, ketika kita tidak dapat menolong diri kita sendiri, jika kita menginginkan hal tersebut, maka kita harus menolong kami melakukannya,

- Jangan menghindari tanggung jawab pribadi bahkan ketika orang lain tidak mau bertanggung jawab untuk kita atau kita merasa tidak perlu bertanggung jawab.

- Prinsip kelakuan baik kepada semua orang lain, karena kita menginginkan orang lain berbuat baik kepada kita. Janganlah melakukan yang buruk kepada orang lain karena kita pun tidak mau dijahati oleh orang lain.

- Prinsip keutamaan kasih di mana jika kita inginkan orang lain berbuat baik kepada kita maka perbuatlah demikian terlebih dahulu, Jadi adalah suatu kelogisan untuk bertindak baik terlebih dahulu, bukan hak untuk diperlakukan baik.

- Jika kita tidak mau bertanggung jawab pada manusia lain, maka kita tidak punya hak untuk meminta pertanggungjawaban sosial dari orang lain.

- Jangan membalas kejahatan dengan kejahatan tetapi balaslah kejahatan dengan kebaikan.

- Prinsip toleransi aktif dalam arti tidak menuntut untuk ditoleransi orang lain karena toleransi yang otentik bukanlah hak tetapi kewajiban manusia.

- Prinsip perdamaian tulus berdasarkan kedamaian hati tidak menolak berdamai dengan musuh sekalipun. Semua manusia sejati ingin kedamaian berdasarkan saling mengampuni dan belas kasihan. 
Demi kebersamaan, masyarakat kota harus saling menahan diri dan saling menerima perbedaan di dalam batas kewajaran seperti tidak menipu, tidak memaksa, tidak mengejek, tidak merusak, tidak menghina dll. Dengan demikian kita dapat mengatasi masalah kemanusiaan secara bersama-sama tanpa saling mencurigai. Sebaliknya kita bahumembahu menghadapi masalah-masalah sosial kota dengan cara-cara damai, persuasif dalam kebaikan, kejujuran, dan persaudaraan. Persaudaraan sesama umat manusia adalah imperatif bagi makhluk agama dan makhluk bermasyarakat seperti manusia, khususnya dalam peradaban manusia modern ini. Dengan demikian ekses politisasi agama maupun agamaisasi politik yang bersifat manipulatif bisa dikurangi atau mungkin dihilangkan.

Masyarakat kota modern yang demokratis harus menghindari apa yang disebut dengan konsep theopolis, baik oleh karena mayoritas maupun pengaruh kekuasaan yang dimunculkan dalam 'kota agama,' meski mayoritasnya dikuasai orang beragama tertentu. Kemudian agama yang murni seharusnya tidak dipolitisir karena sejarah telah membuktikan, sintesis demikian telah merusak agama dan akhirnya merusak tatanan masyarakat itu sendiri. ${ }^{23}$ unsur religius kota tidak boleh diperalat secara fanatik dan munafik untuk kelompok sendiri

${ }^{23}$ Harvey M Conn, "The Kingdom of God and The City of Man: A History of the City/Church Relation" dalam Discipling The City: A Comprehensive Approach to Urban Ministry, Rogers Greenway ed. (Eugene: Wipf and Stock, 1992), 250-256. 
ala fundamentalis agama. Dengan demikian tidak terkotori oleh semangat fanatisme agama yang mungkin dilatarbelakangi sajarah masa lalu. Kalau disimak dengan seksama, sesuai jiwa dan nilai-nilai etika global, walau implementasinya masih sulit dalam kehidupan sehari-hari, namun prinsip hidup bersama untuk menjadi kota warga dunia ini tidak hanya sekadar mimpi atau dikhianati oleh golongan yang tak bertanggung jawab.

Berkaitan dengan pembangunan bangsa, memang negara mempunyai tugas sebagai penyejahtera warganya, seperti misalnya amanat Pembukaan UUD '45. Tentunya dalam hal ini tidak lepas dari kerja sama antar-warganegaranya yang niscaya adalah makhluk agama, makhluk sosial dan makhluk rasional. Ini adalah dasar makhluk rasional sekaligus fondasi pembangunan manusia Indonesia yang seutuhnya dalam kebangsaan, persaudaraan lokal.

Selanjutnya, warga gereja di kotanya disebut secara khusus sebagai kota yang diperhatikan dalam pembicaraan pluralitas di era globalisasi, demikian, "every local church wather in Kansas city or Konsin Toledo, or Tokyo, Jakarta or Bandung - will serve in this era of Globalization. Every local church leader needs to be equipped for interreligious encounter." ${ }^{24}$ Rupanya kota-kota besar di Indonesia sedang disoroti dunia. Oleh karena itu 'suara kenabian' gereja-gereja

${ }^{24}$ Diambil dari pernyataan Max L. Stackhouse "Christ Church and Other Religion," The Local Church in a Global Era, Max L. Stackhouse et.al. eds. (Grand Rapids: Wm. Eerdmans Pub. Co., 2003), 139. 
yang bersifat etis sedang dinantikan demi kesejahteraan penduduk kotanya. Hal ini mengingat prinsip Kerajaan Allah harus menekankan pentingnya keterlibatan orang Kristen dalam masyarakat, seperti yang dimaksudkan John Stott dengan "doktrin lebih genap (lengkap)" yang menyangkut sisi keprihatinan sosial Kristen yang alkitabiah. Jadi suara kenabian gereja sama sekali bukan suara politik. Karena pada prinsipnya institusi gereja tidak boleh dijadikan partisan partai tertentu. Jadi karena gereja bukan kelompok aksi politis, maka hubungan gereja-gereja dengan pemerintah kota adalah dalam hal "mengajar, bukan intervensi" ${ }^{25}$ kekuasaan. Ini suatu yang bersifat moral-etis bukan kekuasaan, yang aksinya bukan kasak-kusuk di dalam tetapi persuasi dari luar dan bersifat konsultatif berdasarkan suara hati nurani sosial dan agen kontrol sosial masyarakat kota.

Dengan demikian gereja-gereja dan masyarakat agama yang lain dapat membantu dalam konteks tugas diakonia dan pembinaan warga gereja, bukan saja dalam keprihatinan dan aksi sosial tetapi juga menciptakan iklim yang kondusif bagi pembangunan bangsa berdasarkan: kebebasan, keadilan, persamaan hak dan kewajiban. Untuk itu tetap harus diingat oleh semua golongan, bahwa 'demokratisasi masyarakat tidak boleh berhenti!" bagi suatu kota modern, untuk itu pendidikan

${ }^{25}$ Lihat Rogers S. Greenway \& Timothy M. Morsma, Cities: Mission New Frontier (Grand Rapids: Baker Book, 1989), 217. Berkaitan dengan itu, secara terpisah selanjutnya Morsma mengingatkan gereja untuk mewaspadai 'suap'. Ibid., 218. 
masyarakat harus ditumbuh-kembangkan dan lapangan kerja harus disediakan, sehingga dapat memahami nilai-nilai universal kemanusiaan, secara global. Sehingga dapat mengatasi gejolak dan ketegangan di masyarakat kota yang pluralistik, khususnya karena perbedaan peribadatan yang berbeda, mengingat "agenda reformasi dalam bidang agama dirasakan terabaikan bahkan dianggap tidak menyentuh masyarakat, dalam arti agama berjalan sendiri mengikuti arus umum kebebasan reformasi, karena kurang kebijakankebijakan umum yang adil, sehingga anarkisme religius merebak di mana-mana. Hal itu tentu jika dibanding reformasi politik, ekonomi, sosial, budaya dll., yang lebih aktif dan mendapat banyak perhatian dan sorotan masyarakat dan pemerintah.

Pemerintah kota, misalnya sebagai institusi sosial kemasyarakatan dengan perangkat legal dan bersifat persuasif dan dalam batas-batas konstitusional dan nasional dapat bersifat koersif untuk menjamin kedamaian setiap golongan masyarakat tanpa diskriminasi, ini bukan berarti militerisme yang melawan prinsip-prinsip masyarakat sipil dan supermasi hukum. Kekerasan (coercion) itu sendiri perlu di dalam masyarakat di dalam batas-batas legalitas, karena tidak percuma pemerintah memegang pedang. Kalau pemerintah yang memegang mandat konstitusi tidak menanggulangi situasi anarkisme sesuai hukum dengan alasan takut dituduh melanggar HAM, maka akan terjatuh dalam pelanggaran HAM juga. 
Sebenarnya dalam tingkat pimpinan pemerintahan sudah ada kesadaran untuk menjadikan kota dengan hidup damai dan aman, sejahtera dalam segala bidang yang melampaui perbedaan agama, ras, suku antar golongan dan keturunan. Dengan tekad ini perbedaan-perbedaan yang ada dapat didamaikan agar tidak menjadi ketegangan dan konflik yang berkepanjangan serta membuat disintegrasi. Dalam slogan kota sebaiknya tertanam nilai-nilai kebersamaan manusia berdasarkan esensi agama yang luhur, seperti: kasih persaudaraan, kedamaian, keadilan, dan kesejahteraan. Tentunya usaha ini bukan suatu usaha yang mudah dan sekejab mata untuk merealisasikannya.

Pentingnya prinsip demokrasi sebagai filsafat hidup manusia yang bermasyarakat majemuk, tidak hanya harus sebagai sistem politik praktis dan prosedur pemerintahan dengan segala agenda kekuasannya dan kekerasannya. Nilainilai demokrasi menjunjung tinggi hakekat umat manusia dengan karakternya, inspirasinya, dan motivasinya dalam lingkungan kemerdekaan, persamaan hak, keutamaan akal dan ketidakpercayaan atas akumulasi kekuasaan dan kesejahteraan, sebagai pandangan optimis tentang manusia di dalam masyarakat plural terutama dalam agama-agama dan hak yang sama bagi seluruh warga negara.

Dalam demokrasi peran masyarakat pada pembangunan bangsa sangat penting dan harus diseimbangkan dengan peran pemerintah sebagai fasilitator pembangunan. Inilah, hakikat people power yang selama ini hanya dimengerti secara negatif sebagai politik praktis yang revolusioner, harus dimengefti 
secara positif di dalam hubungan sosial dan perababan, yaitu suatu partisipasi warga kota sebagai kekuatan positif dalam pembangunan kota. Jadi diperlukan keikutsertaan masyarakat dalam pembangunan kota demi kesejahteraan, kemakmuran, kedamaian, sehingga prinsip esensial demokrasi tidak hilang dari panggung politik, yang disebabkan oleh kepentingan dan kekuasaan sementara. Kalau hal ini terjadi, maka demokrasi melawan dirinya sendiri dan mengalami kemunduran serta tidak dipercaya lagi oleh masyarakat. Demokrasi dan people power yang positif, ada pada level lokal yang multietnik dan multiagama dalam kesatuan perjuangan komunitas. ${ }^{26}$ Dengan segala kerumitannya sebuah kota akan maju atau kacau tergantung warga kotanya sendiri, bukan hanya pemerintahnya saja.

\section{PENUTUP}

Kota-kota modern bersifat pluralistik dan multiperadaban dalam berbagai hal, seperti kota tujuan wisata, perdagangan, pendidikan dan menjadi tempat 'mangkalnya' penduduk dunia ini untuk tujuannya berkunjung. Di sini diperlukan prinsip-prinsip kemanusiaan yang lebih universal dalam toleransi dan antidiskriminasi dalam orientasi kehidupan yang adil di segala aspek kehidupan, berdasarkan persaudaraan umat manusia yang multikultural dalam peradabannya. Sebagai kota untuk semua, seluruh warga kota

${ }^{26}$ Lihat Judith E. Desena, People Power: Grass Roots Politics and Race Relations (Lanham: University Press of America, 1999), viii. 
dan golongan akan mengerti, bahwa 'demokratisasi masyarakat tidak boleh berhenti!" bagi suatu kota modern, dan pendidikan masyarakat harus ditumbuh-kembangkan dan lapangan kerja harus disediakan, sehingga dapat memahami nilai-nilai kemanusiaan global, secara positif.

Umat beragama yang pluralistik adalah pengalamanpengalaman keagamaan bersama, khususnya sebagai umat mencari kebaikan manusia di tengah-tengah dunia. Manusia dan masyarakatnya memerlukan tambahan suatu prinsipprinsip universal kemanusiaan untuk mencapai masyarakat yang adil dan makmur di dalam dunia yang pluralistik ini. Etika global mendeklarasikan nilai-nilai etik minimal dan kebaikan moral kemanusiaan yang berasal dari beragam tradisi-tradisi agama yang ada, khususnya berdasarkan prinsip golden rule dari tiap-tiap agama dunia sebagai titik temu dalam forum dialog sosial. Inti etika global lebih bersifat 'terobosan' hidup bersama dalam masyarakat agama dengan menjadikannya semacam etika 'suplemen' orang-orang beragama yang berbeda adalam rangka mengatasi krisis dalam segala bidang akibat ekses negatif agama. Jadi bukan etika pengganti dari etika agama-agama yang partikular.

Di sini penekanan people building lebih penting daripada city building, agar manfaat pembangunan fisik dapat dirasakan secara riil dalam kesejahteraan hidup sehari-hari atau pembangunan kota harus berimbas pada pembangunan masyarakat, agar warga kota tidak teralienasi dan termarginalisasi akibat pembangunan fisik. Kedua hal ini akan mengakibatkan pembangunan bangsa ini secara utuh. Di masa 
lalu, orde sebelumnya lebih mendahulukan 'pembangunan negara' (state building) ketimbang pembangunan bangsa (nation building). Tidak ada artinya, jika pemerintahan mana pun, hanya berbicara umum dan global tentang angka-angka kemajuan, investasi atau persentasi inflasi bila tidak dirasakan oleh rakyat biasa. Artinya ketika dikatakan inflasi menurun berapa persen, lalu investasi naik, lajur pertumbuhan ekonomi naik berapa persen, tetapi rakyat menderita kemiskinan dan rakyat tidak dapat menjangkau harga beras secara adil. 